ISSN: 1907-9931 (print), 2476-9991 (online)

\title{
ANALISA LOGAM BERAT DALAM DAGING KERANG DARAH (Anadara granosa) DAN KERANG BULU (Anadara antiquata) ASAL PERAIRAN LAUT TELUK LEWOLEBA LEMBATA \\ ANALYSIS OF HEAVY METALS IN KERANG DARAH (Anadara granosa) AND KERANG BULU (Anadara antiquata) FROM LEWOLEBA BAY, LEMBATA
}

\author{
Gerardus Diri Tukan*, Gertreda Latumakulita, Guntildis Riantobi \\ Program Studi Kimia, Matematika dan IImu Pengetahuan Alam, Universitas Katolik Widya Mandira, \\ JIn. Jend. Achmad Yani No.50-52 Kupang - Nusa Tenggara Timur \\ *Corresponden author email: anginwewa@yahoo.co.id
}

Submitted: 15 February 2021 / Revised: 27 December 2021 / Accepted: 31 December 2021

http://doi.org/10.21107/jk.v14i3.9955

\begin{abstract}
This study aims to determine the types of metals and their levels in the samples of Blood Clams (Anadara granosa) and Feather Shells (Anadara antiquata) from the sea of Lewoleba Bay, Lembata district, East Nusa Tenggara province. Both types of shellfish live on Slug Island (Awololong) in the middle of the Lewoleba Bay marine area. The people of Lembata use the two types of shellfish as side dishes and a source of economic income. It is necessary to analyze heavy metal contamination in the marine area of Lewoleba Bay through these two types of shells because human activities have been increasing in the Lewoleba Bay area of Lembata. A total of 100 grams of each sample of dried mussel meat, was destroyed and analyzed for the content of elements and levels of elements, using an X-ray Fluorescence (XRF) spectrophotometer. The results obtained were that the Blood Shellfish sample contained the following elements and levels: $P$ (10\%), S (12\%), K (12\%), Ca (23\%), Cr (0.32\%), $\mathrm{Fe}$ (2.6\%), $\mathrm{Ni}(0.2 \%), \mathrm{Cu}(0.62 \%), \mathrm{Zn}(20.6 \%), \mathrm{Br}(3.4 \%), \mathrm{Mo}(14 \%)$ and $\mathrm{Yb}(0.9 \%)$. Reed Shells samples contain; $P(11.0 \%), S(1.0 \%), K(11.7 \%), C a(39.2 \%), C r(0.62 \%), F e(8.95 \%), \mathrm{Ni}($ $0.4 \%), \mathrm{Cu}(0.49 \%), \mathrm{Zn}(2.4 \%), \mathrm{Br}(1.4 \%), \mathrm{Mo}(22 \%)$ and $\mathrm{Yb}(0.3 \%)$ and $\mathrm{Re}(0.5 \%)$. It appears that both types of samples contain essential heavy metals in the form of $\mathrm{Cu}, \mathrm{Fe}, \mathrm{Zn}$ and $\mathrm{Ni}$, and contain $\mathrm{Cr}$ which is toxic. The Cr content in the Reed Shells samples was higher than that of Blood Clams. The Reed Shells sample also contains the element Re which is a type of rare earth element. Heavy metal levels of $\mathrm{Cu}, \mathrm{Ni}$ and $\mathrm{Cr}$ in both samples exceeded the threshold according to the Decree of the Minister of the Environment of the Republic of Indonesia number 51 of 2004.
\end{abstract}

Keywords: mussel meat, heavy metal, Lewoleba bay sea

\section{ABSTRAK}

Penelitian ini bertujuan untuk mengetahui jenis logam-logam serta kadarnya di dalam sampel daging Kerang Darah (Anadara granosa) dan Kerang Bulu (Anadara antiquata) asal laut teluk Lewoleba kabupaten Lembata propinsi Nusa Tenggara Timur. Kedua jenis kerang tersebut hidup di Pulau Siput (Awololong) yang ada di tengah kawasan laut Teluk Lewoleba. Masyarakat Lembata menjadikan kedua jenis kerang tersebut sebagai lauk pauk serta sumber pendapatan ekonomi. Perlu dilakukannya analisa cemaran logam berat di kawasan laut Teluk Lewoleba melalui kedua jenis kerang tersebut sebab aktivitas manusia telah semakin meningkat di kawasan teluk Lewoleba Lembata. Sebanyak 100 gram masing-masing sampel daging Kerang yang kering, didestruksi dan dianalisis kandungan unsur-unsur serta kadar unsur, menggunakan spektrofotometer X-ray Fluorescence (XRF). Hasil yang diperoleh yaitu sampel Kerang Darah mengandung unsur-unsur serta kadarnya yakni: $P(10 \%), S(12 \%), K$ (12\%), Ca (23\%), Cr (0,32\%), $\mathrm{Fe}(2,6 \%), \mathrm{Ni}(0,2 \%), \mathrm{Cu}$ (0,62\%), Zn (20,6\%), Br (3,4\%), Mo (14\%) dan Yb (0,9\%). Sampel Kerang Buluh mengandung; $P$ (11,0\%), S (1,0\%), K(11,7\%), Ca (39,2\%), Cr (0,62\%), Fe (8,95\%), Ni (0,4\%), Cu (0,49\%), Zn (2,4\%), $\mathrm{Br}(1,4 \%)$, Mo (22\%) dan $\mathrm{Yb}(0,3 \%)$ dan Re (0,5\%). Tampak kedua jenis sampel mengandung logam berat esensial berupa $\mathrm{Cu}, \mathrm{Fe}, \mathrm{Zn}$ dan $\mathrm{Ni}$, serta mengadung $\mathrm{Cr}$ yang bersifat toksik. Kadar $\mathrm{Cr}$ pada sampel Kerang Buluh lebih tinggi dari Kerang Darah. Sampel Kerang Buluh mengandung pula unsur 


\begin{abstract}
Re yang merupakan jenis unsur tanah jarang. Kadar logam berat $\mathrm{Cu}$, Ni dan $\mathrm{Cr}$ pada kedua sampel melampaui ambang batas menurut Keputusan Mentri Lingkungan Hidup Republik Indonesia nomor 51 tahun 2004
\end{abstract}

Kata Kunci: daging kerang, logam berat, laut teluk Lewoleba

\section{PENDAHULUAN}

Perairan laut teluk Lewoleba di kabupaten Lembata propinsi Nusa Tenggara Timur merupakan suatu lingkungan perairan bagi komponen biotik dan abiotik yang mendiaminya. Teluk ini berbentuk setengah lingkaran dan mempunyai luas sekitar 13,46 $\mathrm{km}^{2}$ serta berada di dalam wilayah kota Lewoleba ibu kota kabupaten Lembata. Arus air laut yang masuk ke dalam kawasan teluk ini berasal dari dua arah, yaitu dari selat Boleng, yang merupakan selat antara pulau Lembata dengan pulau Adonara, dan dari selat Lamakera, yakni selat antara pulau Lembata dengan pulau Solor. Selat Boleng merupakan jalur mengalirnya air laut dari laut Flores ke dalam kawasan teluk Lewoleba, sedangkan selat Lamakera merupakan jalur alir air laut dari laut Sawu. Arus air laut dari kedua selat tersebut memasuki teluk Lewoleba dan berpeluang membawa berbagai jenis material yakni biota-biota laut serta partikulat lumpur dan pasir, dan terjebak di dalam teluk Lewoleba.

Profil perairan laut Teluk Lewoleba sebagaimana digambarkan di atas, menyebabkan Teluk Lewoleba tergolong subur, dan memiliki kekayaan biota laut. Di dalam kawasan laut teluk Lewoleba terdapat zona dangkal berpasir yang muncul membentuk daratan jika terjadi pasang surut. Zona dangkal ini seluas kurang lebih $500 \mathrm{~m}^{2}$. Masyarakat Lembata menamakan daratan tersebut sebaga Pulau Siput, atau dalam bahasa daerah setempat disebut Awololong. Terdapat berbagai jenis kerang di Pulau Siput atau Awololong tersebut. Kerang-kerang tersebut selalu dipanen dan dikonsumsi oleh masyarakat Lembata, atau dijual sebagai sumber penghasilan.

Aktivitas memanen kerang dilakukan oleh masyarakat Lembata pada saat pasang surut terjauh dan Pulau Siput membentuk daratan berpasir di tengah laut. Masyarakat menjangkau Pulau Siput tersebut menggunakan perahu. Dua jenis kerang yang dominan dan lebih umum dipanen oleh warga di pulau Awololong ini adalah Kerang Darah (Anadara granosa) dan Kerang Bulu (Anadara antiquata). Kedua jenis kerang ini lebih diminati untuk dipanen karena mempunyai harga jual yang relatif lebih mahal di pasar tradsional di dalam kota Lewoleba.

Kerang Darah merupakan jenis kerang yang tubuhnya mengandung hemoglobin sehingga menyebabkan kerang jenis ini menghasilkan cairan merah (Masindi, 2017). Kerang Bulu mempunyai ciri yakni pada cangkang bagian luarnya terdapat bulu-bulu halus dalam bahasa daerah Lembata, Kerang Darah disebut Kamak Weran dan Kerang Buluh dinamakan Kemuku.

Masyarakat kota Lewoleba khususnya, maupun masyarakat kabupaten Lembata umumnya mengenal dan memanfaatkan kerang-kerang yang dipanen di pulau Siput Awololong sebagai lauk pauk. Aktivitas memanen berbagai jenis kerang serta mengonsumsi daging kerang-kerang tersebut telah dilakukan sejak nenek moyang. Memanen kerang yang dilakukan oleh warga di pesisir pantai teluk Lewoleba pada saat pasang surut, disebut bekarang, dan diikuti oleh ratusan orang, baik orang dewasa maupun anak-anak. Kebiasaan bekarang di tepi pantai tersebut tergolong salah satu kegiatan rekreasi yang dilakukan pada setiap musim pasang surut jauh. Dalam aktivitas bekarang dimaksud, Kerang Darah dan Kerang Bulu yang menjadi buruan utama. Kerang Darah dan Kerang Bulu yang diperoleh, umumnya langsung diolah dan dikonsumsi. Banyak pula warga yang mengolah daging kerang tersebut menjadi kering, yang dikenal dengan istilah lokal yakni kemuku. Kemuku dijual dengan harga yang relatif mahal.

Secara ilmiah, Kerang Darah memiliki kandungan protein rata-rata $9-13 \%$ (Nurjanah et al., 2005), sedangkan Kerang Bulu mempunyai kandungan protein rata-rata 6,79 - 11,92\% (Arnanda et al., 2005). Komposisi kimia kerang sangat bervariasi tergantung pada spesies, jenis kelamin, umur, dan habitat (Suwignyo et al., 2005). Berbagai penelitian ilmiah telah mengungkapkan bahwa daging Kerang Darah dan Kerang Bulu tidak hanya memiliki nilai gizi tetapi bermanfaat pula sebagai antioksidan dan berperan dalam sistem pertahanan tubuh (Nurjanah et al., 2005). Anindyaputri (2019) mengemukakan bahwa terdapat empat manfaat Kerang Darah yakni mengatasi anemia, menjaga kesehatan 
Tukan et al., Analisa Logam Berat Dalam Daging Kerang

jantung, membentuk dan merawat otot, serta menjaga fungsi sistem syaraf. Safitri \& Hanizar (2019) mengemukakan pula bahwa mengonsumsi daging kerang dapat meningkatkan diet yang sehat. Hal ini disebabkan oleh daging kerang berkadar lemak rendah berupa omega-3, merupakan sumber protein, sumber mineral seperti $\mathrm{Fe}$, $\mathrm{Zn}, \mathrm{Cu}$, serta vitamin B-12 Kerang Darah juga diketahui berpengaruh terhadap kesuburan pria, yakni dapat memperbaiki volume, $\mathrm{pH}$, bau,dan warna semen, dan kualitas spermatozoa.

Kerang Darah dan Kerang Bulu yang mempunyai lingkungan hidup yaitu di daerah litoral, berpasir dan lumpur, menyebabkan mobilitasnya lambat, bahkan cenderung di tempat. Dengan menggunakan cangkangnya yang setangkup (bivalvia), kerang dapat mengonsumsi semua komponen yang melewatinya. Menurut Tugaswati (1995), Kerang Darah maupun Kerang Bulu memiliki kemampuan yang besar untuk menyerap logam berat menggunakan cangkangnya. Kerang Darah mengandung logam $\mathrm{Cd}$ yang tinggi, karena mobilitasnya rendah, dan cenderung menetap sehingga proses biokonsentrasi dan bioakumulasi terjadi secara lebih intensif. Darmono (2001) mengemukakan bahwa lantaran pola hidup dan kemampuannya dalam mengakumulasikan logam berat itu maka kerang ini digunakan sebagai bioindikator dalam memonitoring kualitas air laut dari pencemaran logam berat. Menurut Amin et al., (2011), semakin banyak aktivitas manusia baik di darat maupun di pantai maka akan mempertinggi keberadaan logam berat dalam air laut.

Teluk Lewoleba mempunyai peluang cukup tinggi untuk terjadinya ancaman terpaparnya logam berat pada Kerang Darah dan Kerang Bulu, serta berbagai biota laut lainnya. Safitri et al, (2009) mengemukakan bahwa logam berat yang mencemari air laut berasal dari bahan hasil ndustri baja, percetakan dan tinta cetak, logam dan kawat, plastik PVC plastik, cat, minyak, baterai kering dan aki, serta gelas keramik dan ubin. Semua jenis barang tersebut kini merupakan bahan rumah tangga, dan bahan buangan. Logam berat ini terakumulasi dalam tubuh biota yang kemudian dapat sampai di dalam tubuh manusia ketika manusia mengonsumsi biota laut (Wulan et al., 2013).

Dewasa ini, daging Kerang Darah dan Kerang Bulu serta kerang-kerang jenis lainnya yang dipanen oleh masyarakat Lembata di kawasan Teluk Lewoleba dan dikonsumsi sebagai lauk pauk, patut mendapat perhatian pemantauan kualitasnya dari ancaman cemaran logam berat. Hal ini patut dilakukan karena kerang merupakan salah satu sumber protein hewani laut bagi masyarakat Lembata, dan juga sebagai salah satu sumber pendapatan ekonomi. Penelitian yang dilakukan ini bertujuan untuk pemantuan terhadap kualitas dan keaanan salah satu bahan pangan tersebut.

\section{Waktu dan Tempat \\ MATERI DAN METODE}

Analisa terhadap sampel Kerang Darah (Anadara granosa) dilakukan pada bulan Januari tahun 2020, dan analisis terhadap sampel Kerang Bulu ((Anadara antiquata) dilakukan pada bulan Agustus tahun 2020. Sampel Kerang Darah maupun Kerang Bulu diambil di Pulau Siput Teluk Lewoleba (Gambar 1).

\section{Desain Penelitian}

Sampel Kerang Darah dan Kerang Bulu diambil di Pulau Siput (Awololong) Lewoleba Lembata secara acak, dengan menuruti kebiasaan warga mencari atau memanen keran. Sampel kerang untuk masing-masing jenis sampel, dalam keadaan segar, disiapkan beberapa ekor kemudian dibuka cangkangnya. Daging segar dari masingmasing sampel dicuci dengan air tawar dan dijemur hingga kering. Pengeringan sampel dilanjutkan dengan menggunakan oven pada suhu $110^{\circ} \mathrm{C}$ selama 15 menit, secara berulang hingga diperoleh berat konstan. Selanjutnya dilakukan analisis jenis dan kadar unsur yang terkadung di dalam tiap sampel menggunakan spektrofotometri X-Ray Fluoroscence (XRF). 


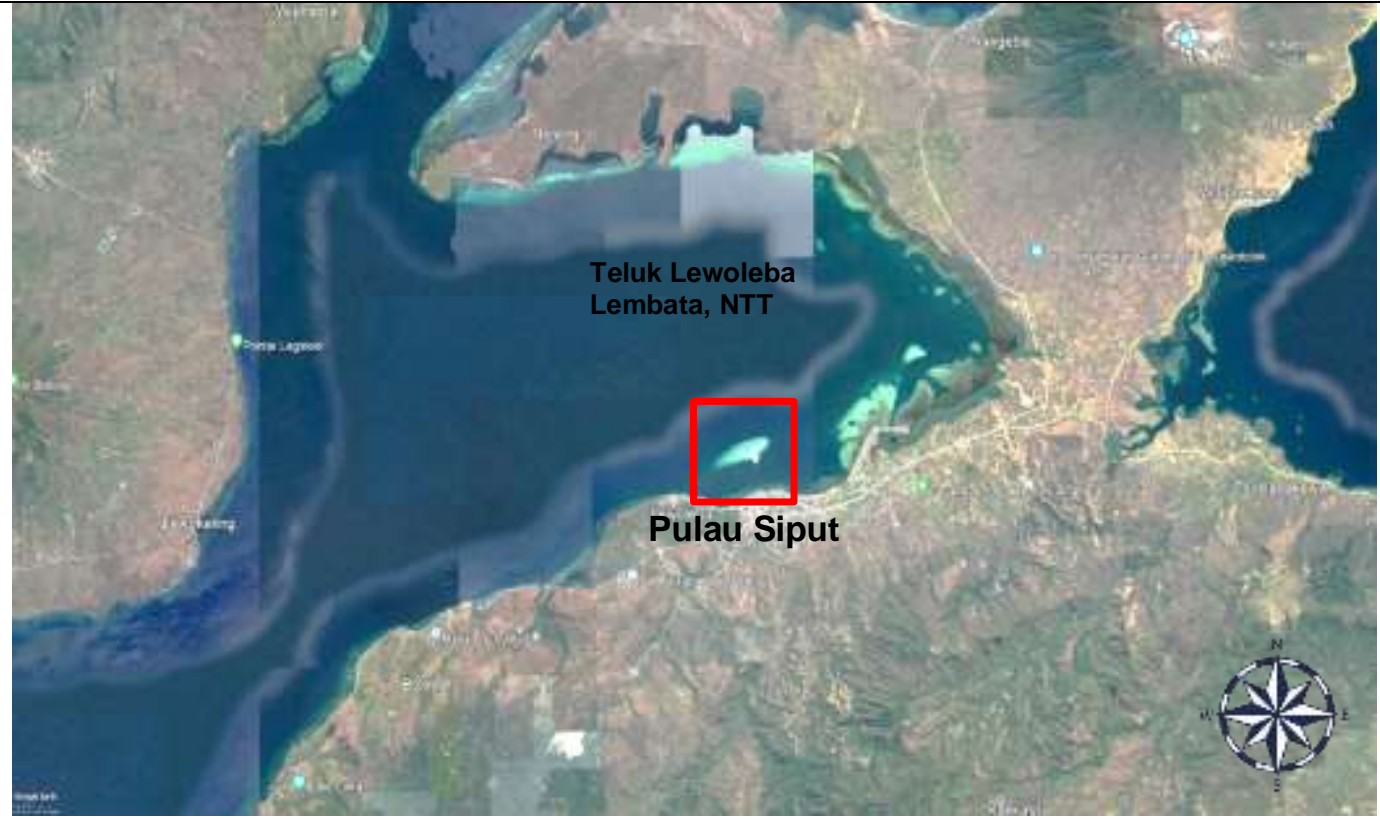

Gambar 1. Pulau Siput di Teluk Lewoleba pulau Lembata

\section{HASIL DAN PEBAHASAN}

Hasil analisis terhadap 100 gram sampel daging kerang kering, secara spektrofotometri $X$-Ray Fluoroscence (XRF), diperoleh data spectra hasil analisis yang dtampilkan dalam Gambar 2, dan jenis-jenis unsur-unsur serta kadar unsur dicantumkan dalam Tabel 1.
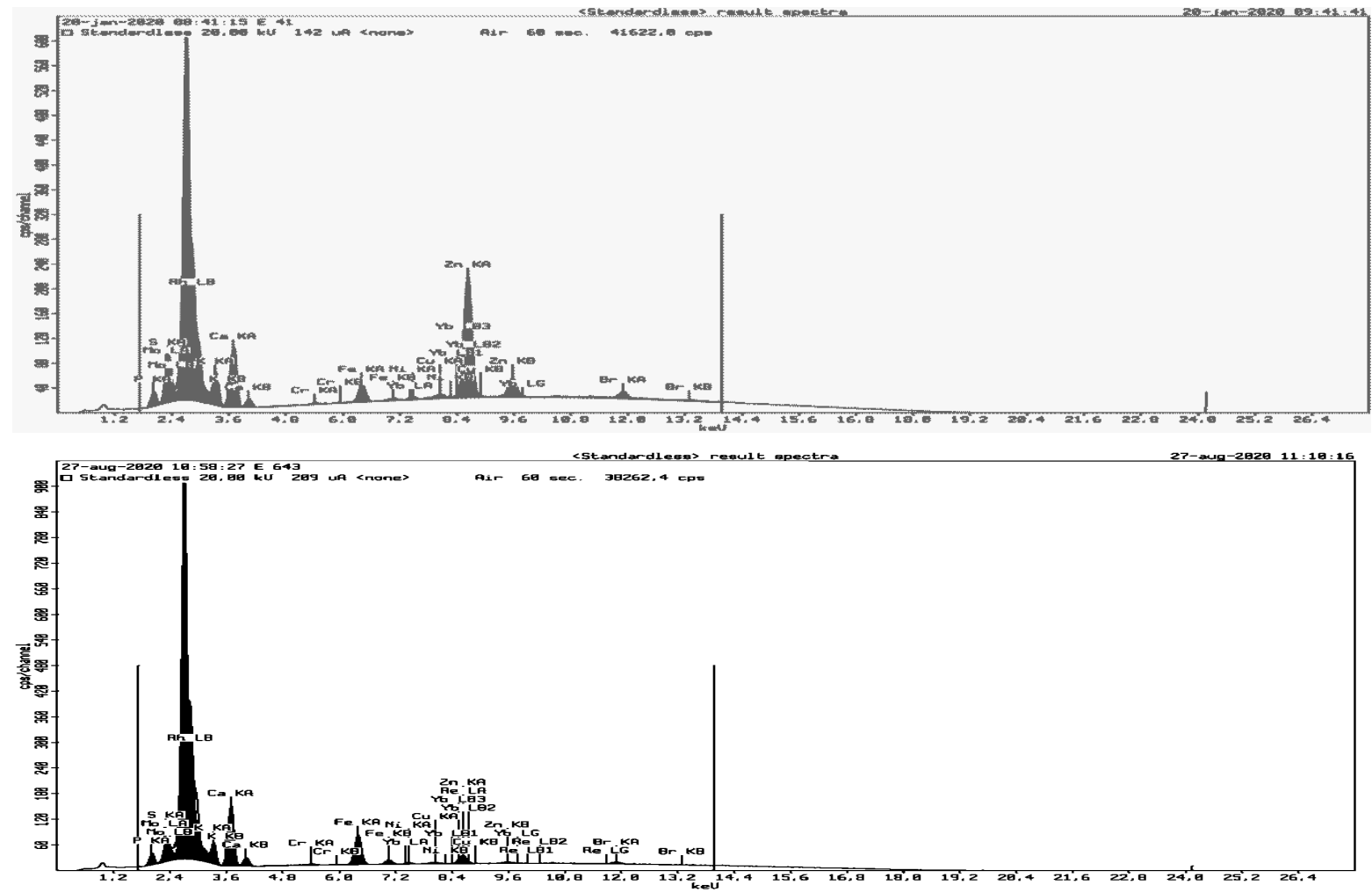

Gambar 2. Spektra hasil analisis unsur-unsur dalam sampel daging (a) Kerang Darah dan (b) Kerang Bulu secara XRF 
Tukan et al., Analisa Logam Berat Dalam Daging Kerang

\begin{tabular}{|c|c|c|c|c|}
\hline No & Jenis Unsur & Jenis sampe & $\operatorname{ar}$ unsur (\%) & Ambang batas \\
\hline & $\begin{array}{c}\text { yang } \\
\text { terkandung }\end{array}$ & $\begin{array}{c}\text { Kerang Darah } \\
\text { (Anadara granosa) }\end{array}$ & $\begin{array}{c}\text { Kerang Bulu } \\
\text { (Anadara antiquata) }\end{array}$ & $\begin{array}{l}\text { KEPMEN LH } \\
\text { No.51 Tahun } \\
2004\end{array}$ \\
\hline 1 & $\mathrm{P}$ & 10,0 & 11,0 & \\
\hline 2 & S & 12,0 & 1,0 & \\
\hline 3 & $\mathrm{~K}$ & 12,0 & 11,7 & \\
\hline 4 & $\mathrm{Ca}$ & 23,0 & 39,2 & \\
\hline 5 & $\mathrm{Cr}$ & 0,32 & 0,62 & 0,002 ppm \\
\hline 6 & $\mathrm{Fe}$ & 2,6 & 8,95 & \\
\hline 7 & $\mathrm{Ni}$ & 0,2 & 0,4 & 0,075 ppm \\
\hline 8 & $\mathrm{Cu}$ & 0,62 & 0,49 & 0,05 ppm \\
\hline 9 & $\mathrm{Zn}$ & 20,6 & 2,4 & $0,1 \mathrm{ppm}$ \\
\hline 10 & $\mathrm{Br}$ & 3,4 & 1,4 & \\
\hline 11 & Mo & 14,0 & 22,0 & \\
\hline 12 & $\mathrm{Yb}$ & 0,9 & 0,3 & \\
\hline 13 & $\operatorname{Re}$ & & 0,5 & \\
\hline
\end{tabular}

Hasil analisis diperoleh data bahwa sampel daging Kerang Darah mengandung 12 jenis unsur, sedangkan sampel Kerang Bulu mengandung 13 jenis unsur. Kadar dari setiap unsur pada kedua jenis sampel tampak berbeda. Pada kedua sampel, kadar tertinggi adalah unsur kalsium (Ca). Pada sampel Kerang Darah, kadar terendah adalah unsur Nikel (Ni), sedangkan pada sampel Kerang Bulu yaitu unsur $\mathrm{Yb}$. Sampel Kerang Bulu mengandung pula unsur Re, sedangkan unsur tersebut tidak terdapat pada sampel Kerang Darah.

Kedua jenis sampel diketahui mengandung logam berat esensial berupa $\mathrm{Cu}$, , $\mathrm{Fe}, \mathrm{Zn}$ dan $\mathrm{Ni}$ dengan kadar yang berbeda cukup menyolok, terutama kandungan logam $\mathrm{Zn}$. Logam-logam ini tergolong logam berat esensial, yakni logam-logam berat yang dalam jumlah tertentu sangat dibutuhkan oleh organisme untuk kelangsungan hidupnya. Jika dalam jumlah berlebih maka akan menimbulkan toksik.

Kedua jenis sampel juga mengadung logam berat non esensial, (logam berat yang bersifat toksik) yakni $\mathrm{Cr}$. Kandungan logam $\mathrm{Cr}$ pada sampel Kerang Darah adalah 0,32\% dan pada sampel Kerang Bulu sebesar 0,62\%. Kadar tersebut melampaui ambang batas yang disyaratkan oleh KEPMEN LH No.51 Tahun 2004 yakni sebesar 0,002 ppm. Kehadiran logam $\mathrm{Cr}$ di dalam sampel, menjadi hal yang menarik untuk dikaji. Menurut Chusein \& Ibrahim (2012), penetrasi logam Cr ke dalam kerang, lebih lemah daripada logam $\mathrm{Cd}$, Hal itu berarti bahwa kandungan $\mathrm{Cr}$ di dalam sampel yang dianalisis, seharusnya sangat rendah atau bahkan nihil. Namun data yang diperoleh dalam penelitian ini bahwa tubuh sampel mengandung logam $\mathrm{Cr}$.

Kehadiran logam $\mathrm{Cr}$ di dalam sampel, diduga berasal dari limbah rumah tangga. Menurut Nuraini et al., (2017), logam Cr berada di dalam suatu lingkungan perairan berasal dari alam dan juga dari limbah aktivitas manusia. Sumber dari alam berasal dari proses pelapukan batuan dan run-off dari daratan, namun jumlahnya sangat kecil. Kadar $\mathrm{Cr}$ di dalam tubuh air dapat meningkat dengan jumlah yang besar akibat limba industri dan limbah rumah tangga. Logam $\mathrm{Cr}$ di dalam tubuh perairan bersumber dari faktor manusia, dapat berlangsung secara antropogenik. Misalnya, dari minyak dan aktivitas kapal laut, dari limbah pertanian (pupuk dan pestisida), serta limbah domestik (Azhar et al., 2012).

Yunus et al., (2014) mengemukakan bahwa logam $\mathrm{Cr}$ yang ada dalam tubuh kerang di perairan laut, dapat berasal dari pupuk dari industri pertanian, emisi dari kendaraan bermotor, dan dari pengecoran baja dasar. Polutan $\mathrm{Cr}^{6+}$ dapat pula berasal dari industri energi, pembuatan logam dan bahan kimia (Tumolo et al., 2020). Menurut Rahman et al., (2007), logam chrom dalam bentuk ion $\mathrm{Cr}^{6+}$ merupakan logam berat polutan air yang bersifat racun terhadap banyak organisme. Hal ini terjadi karena ion $\mathrm{Cr}^{6+}$ bersifat pengoksidasi kuat yang sangat larut dalam air dan membentuk anion kromat $\left(\mathrm{CrO}_{4}^{-2}\right)$ dan dikromat $\left(\mathrm{Cr}_{2} \mathrm{O}_{7}^{-2}\right)$. Jika ion $\mathrm{Cr}^{6+}$ terpapar dalam jumlah besar di dalam sistem biologis maka dapat menembus membran seluler dan direduksi menjadi ion $\mathrm{Cr}^{3+}$ di mitokondria dan dapat berinteraksi dengan asam nukleat dalam proses produksi protein. Azam et al., 
Jurnal Kelautan, 14(3), 263-272 (2021)

(2007) mengemukakan bahwa logam chrom mencemari tubuh air berasal dari industri pencelupan tekstil. Sumber $\mathrm{Cr}$ yang lain yaitu industri karet dan industri kabel (Nuraini et al., 2017).

Berdasarkan pendapat ini, dapat dikemukakan bahwa kehadiran logam $\mathrm{Cr}$ dalam tubuh sampel dapat berasal dari sumber-sumber non alamiah, dan kadarnya di dalam tubuh air laut tergolong tinggi, sehingga dapat terserap ke dalam tubuh sampel. Bagi perairan laut Teluk Lewoleba Lembata, sumber $\mathrm{Cr}$ diduga berasal dari limbah domestik serta aktivitas pelayaran di dalam kawasan teluk tersebut. Hal itu dapat terjadi karena teluk Lewoleba sedang mengalami peningkatan pemukiman dan aktivitas manusia. Sumber polutan $\mathrm{Cr}$ dari limbah rumah tangga pun dapat bersumber pada aliran arus air laut dari selat Boleng maupun dari selat Lamakera (Gambar 3). Terkait sumber $\mathrm{Cr}$ yang dapat berasal dari limbah pertanian, hal ini dapat terjadi dari limbah persawahan Urimitem Waikomo Lewoleba, karena sungai dari persawahan tersebut dapat mengalir memasuki laut Teluk Lewoleba.

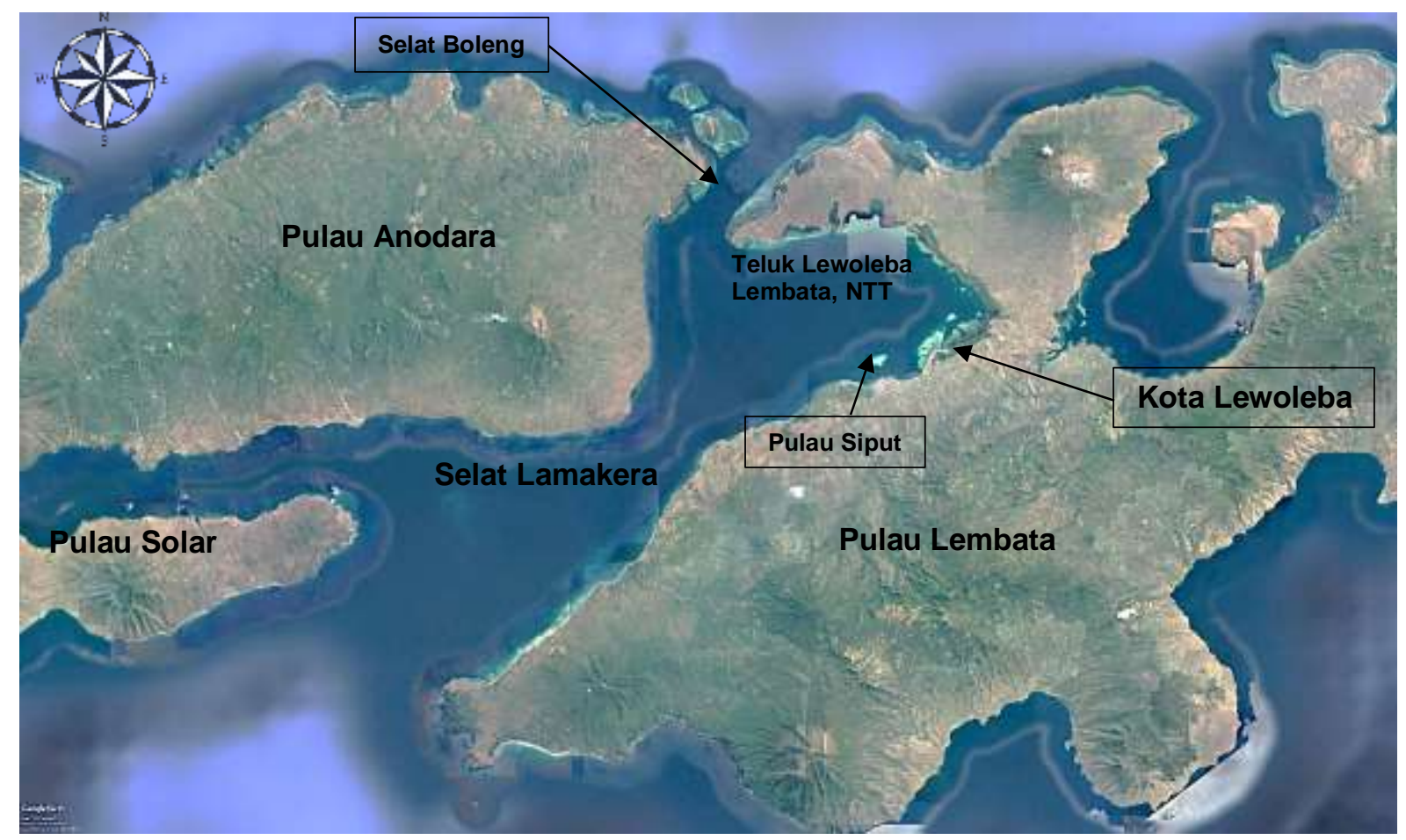

Gambar 3. Teluk Lewoleba Lembata

Unsur fosfor $(P)$ di dalam sampel merupakan salah satu jenis unsur yang berperan dalam proses metabolisme organisme laut. Unsur ini ada di dalam tubuh air laut, dapat bersumber dari lapisan tanah. Edwar \& Manik (1987) serta Hutagalung \& Rozak (1997) yang dikutip Makatita et al., 2014) menguraikan bahwa fosfor alam bentuk ion fosfat di dalam air, merupakan salah satu zat hara yang penting dalam proses pertumbuhan dan metabolisme organisme laut. Ion-ion fosfat dalam bentuk $\mathrm{H}_{2} \mathrm{PO}_{4}^{-}, \mathrm{HPO}_{4}{ }^{2--}$, dan $\mathrm{PO}_{4}{ }^{3-}$, diabsorbsi oleh fitoplankton dan masuk ke dalam rantai makanan.

Unsur Cu di dalam sampel dan dengan kadar yang cukup besar, dapat menjadi petunjuk bahwa perairan laut teluk Lewoleba diduga telah tercemar logam berat $\mathrm{Cu}$. Logam $\mathrm{Cu}$ dapat bersumber dari limbah pertanian. $\mathrm{Di}$ dunia pertanian, unsur $\mathrm{Cu}$ sebagai salah satu unsur mikro esensial untuk et al., 2018). Logam $\mathrm{Cu}$ termasuk salah satu logam yang dimanfaatkan pada pembuatan pupuk dan pestisida, sehingga dapat menjadi sumber pencemaran yang berasal dari limbah pertanian (Mahendra et al., 2018). Logam Cu yang berada di perairan dapat berasal dari aliran sungai yang membawa pestisida sampai ke laut, serta adanya aktivitas pengecatan kapal guna melindungi lambung kapal dari perkaratan (Falah et al., 2018) Berdasarkan uraian ini maka sumber $\mathrm{Cu}$ di dalam tubuh sampel dapat berasal dari limbah pertanian persawahan Waikomo Lewoleba, dan juga dari aktivitas nelayan dan aktivitas dermaga laut Lewoleba. Kandungan $\mathrm{Cu}$ dalam kedua sampel lebih tinggi daripada yang ditetapkan dalam KEPMEN LH No.51 Tahun 2004 
Tukan et al., Analisa Logam Berat Dalam Daging Kerang

Logam Zn merupakan salah satu jenis logam berat yang dibutuhkan dalam pembentukan haemosianin dalam system dara dan enzimatik pada hewan air, termasuk pada Kerang Darah. Keberadaan logam Zn yang berlebih di dalam tubuh sampel, dapat .berasal dari limbah domestik, industri perikanan, pertanian dan kegiatan transportasi laut. Akumulasi logam Zn pada sedimen menyebabkan terjadi penumpukan di dasar perairan (Amriani et al., 2011), sehigga dapat diserap oleh kerang. Kandungan $\mathrm{Zn}$ dalam kedua sampel lebih tinggi daripada yang ditetapkan dalam KEPMEN LH No.51 Tahun 2004.

Unsur $\mathrm{Fe}$ di dalam tubuh sampel yang dianalisis, dapat merupakan komponen alamiah di dalam tubuh kerang, dan dapat pula berasal dari lingkungan. Pada hewan laut, unsur Fe banyak terdapat pada daging yang berwarna merah. Menurut Nurjanah et al (2005), logam Fe terdapat pada jaringan yang membentuk kompleks bersama protein. Kandungan logam $\mathrm{Fe}$ di dalam air laut yang dapat terinflitrasi ke dalam tubuh kerang, berasal dari luar air laut. Ika et al., (2012) mengemukakan bahwa logam $\mathrm{Fe}$ di dalam air laut dapat bersumber dari pengikisan batuan mineral akibat hempasan gelombang dan angin, perkaratan kapal-kapal laut dan tiangtiang pancang pelabuhan yang mudah berkarat.

Unsur nikel (Ni) merupakan suatu logam berat. Keterdapatan $\mathrm{Ni}$ dalam daging kerang merupakan salah satu mineral mikro yang diperlukan dalam proses metabolisme. Namun, kandungan $\mathrm{Ni}$ yang tinggi dapat menunjukkan bahwa telah terjadi pencemaran. Logam Ni dapat masuk ke dalam tubuh air laut dan mencemari biota laut, berasal dari limbah industri, misalnya sebagai katalisator, fungisida maupun sebagai additif, bahan campuran logam, elektro-plating, (Hutagalung, 1984). Kehadiran logam Ni di dalam laut teluk Lewoleba dan terserap masuk ke dalam tubuh kerang, dapat berasal limbah domestik, yakni bahan-bahan yang mengandung $\mathrm{Ni}$. Kandungan $\mathrm{Ni}$ dalam kedua sampel lebih tinggi daripada yang ditetapkan dalam KEPMEN LH No.51 Tahun 2004

Unsur Ca di dalam sampel tampak mempunyai kadar yang lebih tinggi. Keberadaan $\mathrm{Ca}$ di dalam sampel ini berkaitan erat dengan kebutuhan $\mathrm{Ca}$ dalam proses pembentukan cangkang. Kerang menggunakan zat kapur $\left(\mathrm{CaCO}_{3}\right)$ di dalam air serta zat-zat organik lainnya untuk membentuk cangkang sebagai pelindung tubuhnya.
Pemanfaatan $\mathrm{Ca}$ untuk pembentukan cangkang ini berlangsung sejak menjadi larva glokidium dalam proses pembiakannya. Kastawi (2005) yang dikutip oleh Nur (2017) menguraikan bahwa proses metabolisme dalam tubuh larva kerang membentuk satu komponen tubuh yakni prismatic. Komponen ini merupakan lapisan tengah pada cangkang. Lapisan ini tersusun oleh kristal-kristal $\mathrm{CaCO}_{3}$. Secara fisik, lapisan $\mathrm{CaCO}_{3}$ ini putih, bersih, dan bahkan berkilau.

Kandungan unsur Kalium (K) di dalam sampel tergolong tinggi. Hal ini dapat terjadi karena sampel dalam proses hidupnya, menyerap air laut, dimana air laut mengandung salah satu jenis garam yaitu KCl. Soetan et al., (2010) yang dikutip oleh Srimariana et al., (2015) mengemukakan bahwa di dalam sistem hidup makhluk hidup, termasuk kerang, ion $\mathrm{K}^{+}$ terdapat di dalam cairan intraseluler dan berfungsi menjaga keseimbangan asam basa sel. Kalium juga berperan dalam reaksi-reaksi enzimatis pada proses glycogenesis dan transfer fosfat dari ATP menjadi asam piruvat.

Unsur Brom $(\mathrm{Br})$ yang terkadung di dalam sampel yang dianalisis, berasal dari senyawa garam di dalam air laut, seperti garam magnesium dan garam logam alkali lainnya (Anugrah, 2013). Kehadiran unsur Molibdenum (Mo) di dalam sampel diperkirakan merupakan salah satu unsur atau elemen mayor di dalam air laut, dan berasal dari larutnya mineral lain yang mengandung Mo, terutama logam tembaga.

Keterdapatan unsur $\mathrm{Yb}$ di dalam sampel yang dianalisis, dapat diduga berasal dari bahan cemaran yang masuk ke dalam tubuh ait lut di daerah pengambilan sampel. Bahan cemaran yang mengandung Ytterbium misalnya buangan dari bahan paduan logam besi baja, limbah ukiran dan produk-produk organik. Sebab, unsur Yb merupakan satu jenis logam Tanah Jarang yang digunakan dalam industri laser inframerah dan agen pereduksi kimia (Atmawinata et al., 2014). Ytterbium digunakan dalam paduan dan ditambahkan ke stainless steel untuk meningkatkan penyempurnaan dan kekuatan paduan logam dalam pemahatan dan ukiran. Senyawa Yterbium digunakan sebagai katalis dalam industri kimia organik (Anwar, 2018). Dengan demikian, bahan limbah yang mengandung unsur $\mathrm{Yb}$ dan dibuang ke laut, dapat menjadi sumber cemaran dan dapat menjangkau sampel yang dianalisis.

Sampel daging Kerang Bulu mengandung pula unsur Rhenium $(\mathrm{Re})$. Unsur Re merupakan 
salah satu jenis unsur paling langka dalam kerak bumi. Dalam kehidupanmanusia, unsur $R e$ ini digunakan dalam bentuk logam paduan bersama logam lain dan dalam jumlah yang sedikit. Unsur $R e$ merupakan salah satu produk sampingan dari ekstraksi pemurnian unsur Mo dan $\mathrm{Cu}$. Unsur Re dalam bentuk Renium oksida, digunakan sebagai katalis padat pada reaksi metatesis olefin (Johanne, 1999). Digunakan juga sebagai katalis pada poses hidrogenasi dan isomerasi pengubahan naftas kilang minyak bumi guna menghasilkan bensin oktan tinggi. Kehadirannya dalam sampel yang dianalisis, diduga berasal dari material kerak bumi setempat, atau dari limbah domestik yang mengandung Re.

Kehadiran logam berat di dalam sampel yang dianalisis, diduga berasal dari peningkatan aktivitas pelabuhan laut kota Lewoleba serta meningkatnya jumlah penduduk yang bermukim di kota tersebut yang berpengaruh terhadap peningkatan limbah domestik yang memasuki badan air laut Teluk Lewoleba. Peningkatan jumlah penduduk di kota dimulai ketika kota Lewoleba menjadi ibukota kabupaten Lembata, sejak Lembata menjadi suatu kabupaten definitif, tahun 1999. Dugaan lain yaitu logam berat yang bersumber dari aliran arus laut yang mengalir memasuki kawasan Teluk Lewoleba dan terakumulasi di dalam kawasan teluk tersebut.

\section{Kesimpulan \\ KESIMPULAN DAN SARAN}

Berdasarkan data hasil penelitian ini maka dapat disimpulkan bahwa: sampel daging Kerang Darah (Anadara granosa) dan Kerang Bulu (Anadara antiquata) asal perairan teuk Lewoleba mengandung logam berat $\mathrm{Cu}, \mathrm{Cr}$, $\mathrm{Zn}$ dan $\mathrm{Ni}$ yang melampaui ambang batas seperti ditetapkan dalam KEPMEN LH No.51 Tahun 2004 tentang Baku Mutu Air Laut. Sampel yang dianalisis juga mengandung logam-logam yang jarang namun bermanfaat, yaitu $\mathrm{Yb}$ dan $\mathrm{Re}$

\section{Saran}

Berdasarkan hasil penelitian ini maka disarankan agar dilakukan penelitian terhadap kerang jenis lain yang terdapat di perairan teluk Lewoleba, serta diperluas sampling guna mengkaji jenis-jenis logam lain serta kadarnya. Dilakukan pula analisis logam-logam di dalam air laut dan sedimen dalam kawasan Teluk Lewoleba.

\section{DAFTAR PUSTAKA}

Amin, B., Afriyani, E., \& Saputra, M. A. (2011). Distribusi spasial logam $\mathrm{Pb}$ dan $\mathrm{Cu}$ pada sedimen dan air laut permukaan di perairan Tanjung Buton Kabupaten Siak Provinsi Riau. Jurnal teknobiologi, 2(01), 1-8

Amriarni, A., Hendrarto, B., \& Hadiyarto, A. (2011). Bioakumulasi logam berat timbal $(\mathrm{Pb})$ dan seng $(\mathrm{Zn})$ pada kerang darah (Anadara granosa L.) dan kerang bakau (Polymesoda bengalensis L.) di perairan Teluk Kendari. Jurnal IImu Lingkungan, 9(2), 45-50.

Anindyaputri I., (https://hellosehat.com., Ayo, Makan Kerang! Ini 4 Manfaat Mujarabnya untuk Kesehatan., diakses 10 Pebruari 2019)

Anugrah, P.T. (2013). Oceanografi, Komponen Mayor Dan Minor Air Laut. Program Studi IImu Kelautan. Jurusan Pemanfaatan Sumberdaya Perikanan dan IImu Kelautan. Fakultas Perikanan dan IImu Kelautan. Universitas Brawijaya. Malang.

Anwar, T. (2018). Sifat, Pembuatan, Kegunaan dan Sumber Dari Unsur Ytterbium., https://sainskimia.com/sifatpembuatan-kegunaan-dan-sumber-dariunsur-ytterbium/

Arnanda, A. D., Ambariyanto, A., \& Ridlo, A. (2005). Fluktuasi kandungan proksimat kerang bulu (Anadara inflata Reeve) di perairan pantai Semarang. ILMU KELAUTAN: Indonesian Journal of Marine Sciences, 10(2), 78-84.

Atmawinata, A., Yahya, F., Widhianto, S., Roosmariharso, D. I., Adriano, A., Susilo, Y., ... \& Sutjiatmo, B. P. (2014). Ardhana, Telaah penguatan struktur industri pemetaan potensi logam tanah jarang di Indonesia,[Study of strengthening industrial structure mapping of rare earth metal potential in Indonesia]. Kementerian Perindustrian Republik Indonesia.

Azhar, H., Widowati, I., \& Suprijanto, J. (2012). Studi kandungan logam berat $\mathrm{Pb}, \mathrm{Cu}$, $\mathrm{Cd}$, Cr pada kerang simping (Amusium pleuronectes), air dan sedimen di Perairan Wedung, Demak serta analisis maximum tolerable intake pada manusia. Journal of Marine Research, 1(2), 35-44.

Al Chusein, A. F., \& Ibrahim, R. (2012). Lama Perendaman Daging Kerang Darah (Anadara granosa) Rebus Dalam Larutan Alginat Terbadap Pengurangan 
Kadar Kadmium. Jurnal Saintek Perikanan, 8(1), 19-25.

Darmono. (2001). Lingkungan hidup dan pencemaran, Hubungannya dengan toksikologi Senyawa Logam., UI Press, Jakarta

Falah, S., Purnomo, P. W., \& Suryanto, A. (2018). Analisis logam berat $\mathrm{Cu}$ dan $\mathrm{Pb}$ pada air dan sedimen dengan kerang hijau (P. Viridis) di Perairan Morosari Kabupaten Demak. Management of Aquatic Resources Journal (MAQUARES), 7(2), 222-226.

Fauziah F, Wulansari R., Rezamel E., 2018., Pengaruh Pemberian Pupuk Mikro Zn dan Cu serta Fauziah, F., Wulansari, R., \& Rezamela, E. (2018). Pengaruh pemberian pupuk mikro Zn dan Cu serta pupuk tanah terhadap perkembangan Empoasca sp. pada areal tanaman teh. Agrikultura, 29(1), 26-34.

Hutagalung, H. P. (1984). Logam berat dalam lingkungan laut. Pewarta Oceana $I X, 1$, 45-59.

Ika, Tahril, Said I. (2012). Analisis Logam Timbal $(\mathrm{Pb})$ dan Besi $(\mathrm{Fe})$ dalam Air Laut di Wilayah Pesisir Pelabuhan Ferry Taipa Kecamatan Palu Utara. J. Akad. Kim, 1(4), 181-186

Mol, J. C. (1999). Olefin metathesis over supported rhenium oxide catalysts. Catalysis Today, 51(2), 289-299.

Keputusan Menteri Lingkungan Hidup Republik Indonesia Nomor No.51 Tahun 2004, tentang Baku Mutu Air Laut., Jakarta.

Azam, M., Firdausi, K. S., Khairani, N., \& Soeleman, S. (2007). Penentuan kandungan unsur krom dalam limbah tekstil dengan metode analisis pengaktifan neutron. Berkala Fisika, 10(1), 35-43.

Mahendra, R., Siaka, I. M., \& Suprihatin, I. E. (2018). Bioavailabilitas Logam Berat Pb Dan Cd Dalam Tanahperkebunan Budidaya Kubis Di Daerah Kintamani Bangli. Ecotrophic, 2(1)

Makatita, J. R., Susanto, A. B., \& Mangimbulude, J. C. (2014). Kajian zat hara fosfat dan nitrat pada air dan sedimen padang lamun Pulau Tujuh Seram Utara Barat Maluku Tengah. In Seminar Nasional FMIPA-UT (Vol. 23).

Masindi, T. (2017). Karakterisasi Kitosan Dari Cangkang Kerang Darah (Anadara granosa). Unesa Journal of Chemistry, 6(3).

Nuraini, R. A. T., Endrawati, H., \& Maulana, I. R. (2017). Analisis kandungan logam berat kromium $(\mathrm{Cr})$ pada air, sedimen dan kerang hijau (Perna viridis) di

perairan Trimulyo Semarang. Jurnal Kelautan Tropis, 20(1), 48-55.

Nurjanah, Z., \& Kustiyariyah, K. M. (2005). Proksimat Kerang Darah (Anadara granosa) Yang Diambil Dari Kabupaten Boalemo, Gorontalo. Buletin Teknologi Hasil Perikanan, 8(2), 1-4

Nur, T. (2017). Studi keanekaragaman kerangkerangan (kelas bivalvia) di Pantai Teluk Bogam Kecamatan Kumai Kabupaten Kotawaringin Barat (Doctoral dissertation, IAIN Palangka Raya).

Nuraini, R. A. T., Endrawati, H., \& Maulana, I. R. (2017). Analisis kandungan logam berat kromium $(\mathrm{Cr})$ pada air, sedimen dan kerang hijau (Perna viridis) di perairan Trimulyo Semarang. Jurnal Kelautan Tropis, 20(1), 48-55.

Rahman, M. U., Gul, S., \& Haq, M. Z. U. (2007). Reduction of chromium (VI) by locally isolated Pseudomonas sp. C171. Turkish Journal of Biology, 31(3), 161-166.

Safitri, N. A., Rifardi, R., \& Hamidy, R. (2009). Konsentrasi logam berat ( $\mathrm{Cd}$ dan $\mathrm{Pb}$ ) pada sedimen permukaan perairan Teluk Bayur Provinsi Sumatera Barat Indonesia. Jurnal Ilmu Lingkungan, 3(02), 85-94.

Safitri, N., \& Hanizar, E. (2019). Efek Konsumsi Kerang Bulu (Anadara antiquata) Terhadap Kuantitas Dan Kualitas Spermatozoa. Al-Kauniyah: Jurnal Biologi, 12(2), 207-219.

Srimariana, E. S., Silaban, B. B., \& Lokollo, E. D. I. R. (2015). Potensi kerang manis (Gafrarium tumidum) di pesisir pantai Negeri Laha, Teluk Ambon sebagai sumber mineral. In Prosiding Seminar Nasional Masyarakat Biodiversiti Indonesia, 4(1), 843-847

Suwignyo, S., Widigdo, B., Wardiatno, Y., \& Krisanti, M. (2005). Avertebrata air untuk mahasiswa perikanan Jilid 2. Bogor: Fakultas Perikanan dan IImu Kelautan, Institut Pertanian Bogor.

Tugaswaty A. T. (1995). Kandungan Logam Kadmium dalam Biota Laut Jenis Kerang-Kerangan dari Teluk Jakarta. Pusat Penelitian Ekologi Kesehatan, Badan Penelitian dan Pengembangan Kesehatan, Departemen Kesehatan RI Jakarta

Tumolo, M., Ancona, V., De Paola, D., Losacco, D., Campanale, C., Massarelli, C., \& Uricchio, V. F. (2020). Chromium pollution in European water, sources, health risk, and remediation strategies: an overview. International journal of 
environmental research and public health, 17(15), 5438.

Wulan, S. P., \& Thamrin \&Amin, B. (2013). Konsentrasi, distribusi dan korelasi logam berat pb, cr dan zn pada air dan sedimen di perairan sungai Siak sekitar Dermaga PT. Indah Kiat Pulp and Paper Perawang-Provinsi Riau, Pusat Penelitian Lingkungan Hidup Universitas Riau.

Yunus, S. M., Hamzah, Z., Ariffin, N. A. N., \& Muslim, M. B. (2014). Cadmium, chromium, copper, lead, ferrum and zinc levels in the cockles (Anadara granosa) from Kuala Selangor, Malaysia. Malaysian Journal of Analytical Sciences, 18(3), 514-521. 